\title{
Uma Instituição de Formação de Professores do Ensino Primário em Coimbra (1942-1974)
}

\author{
Luís Mota \\ António Gomes Ferreira" \\ 'Instituto Polítécnico de Coimbra (IPC) - Portugal \\ "Universidade de Coimbra (UC) - Portugal
}

RESUMO - Uma Instituição de Formação de Professores do Ensino Primário em Coimbra (1942-1974). O artigo, centrado na Escola do Magistério Primário de Coimbra, entre 1942 e 1974, constitui um recorte de uma investigação mais vasta sobre as instituições públicas de formação de professores do ensino primário, em Coimbra, nos séculos XX e XXI. Com recurso ao arquivo, à memória e ao museu analisámos espaços e estrutura arquitetónica, as áreas pedagógica e didática, bem como a dimensão sociocultural. A partir da triangulação de dados delineamos o modelo pedagógico da EMPC e salientamos dimensões de mudança e permanência, bem como de rutura (e conformidade) entre a norma e as práticas sociais.

Palavras-chave: Ensino Normal. Magistério Primário. Estado Novo.

ABSTRACT - A Teacher Training Institution of Elementary Education in Coimbra (1942-1974). The article focuses on the Elementary Teaching Training School of Coimbra (EMPC) (1942-1974). It is a cross-section of a wider research on public institutions of Elementary Teaching Training in Coimbra, in the twentieth and twenty-first centuries. Using archives, the memory and the museum, we studied spaces and architectural structure, the pedagogical and didactic fields and the socio-cultural dimension. Data triangulation allowed us to define the pedagogical model of EMPC. We highlight dimensions of change and permanence, as well as rupture (and conformity) between the norm and the social practices.

Keywords: Teacher Training. Elementary Level Teaching. Estado Novo.

Educação \& Realidade, Porto Alegre, v. 41, n. especial, p. 1397-1418, dez. 2016. 1397 http://dx.doi.org/10.1590/2175-623667658 
As origens, a par das motivações, das instituições educativas resultam, em larga maioria das vezes, de um conjunto de peculiaridades que as particularizam (Sanfelice, 2006). A escola do magistério primário de Coimbra insere-se na tradição de institucionalização do ensino normal primário que, em Portugal, se pode fixar, com segurança, em 1862, na escola normal para o sexo masculino de Marvila que viria a funcionar no palácio dos marqueses de Abrantes. Todavia, o desenvolvimento deste ensino teve as suas hesitações e controvérsias. Foi apenas em 1942 que o Estado Novo consignou, definitivamente, o modelo escolar como o mais adequado à formação de professores e estabeleceu as escolas do magistério primário como "[...] estabelecimentos de ensino oficial destinados a ministrar a cultura e a prática pedagógica" (Portugal, 1942, p. 1140) e responsáveis por fornecer aos seus alunos, em dois anos, a preparação necessária para o desempenho da função de professor do ensino primário.

A diferenciação das instituições educativas ocorre, ainda, dos seus destinatários ou, se preferirmos, dos públicos que as frequentam, seja pela sua idade cronológica ou pelas suas origens espaciais ou socioeconómicas. No caso vertente, a admissão às escolas do magistério só poderia realizar-se entre os dezasseis e os vinte e oito anos de idade, o que, desde logo, diferenciava estas instituições das demais do sistema educativo português. Contudo, concitava, ainda, uma potencial e significativa diferença entre as próprias escolas do magistério, abrindo espaço a diversas variantes de composições etárias do corpo discente.

A presença de culturas e conjunto de valores distintos, mais ou menos próximos da cultura escolar oficial, não deixa de contribuir para uma adequação do projeto pedagógico de cada escola. Mesmo considerando os nove anos de escolaridade, já que a admissão às escolas do magistério primário exigia o diploma do $2^{\circ}$ ciclo liceal ou equivalente e o exame de admissão, escrito e oral, versando as disciplinas de português, matemática e geografia-história, tenham contribuído para esbater diferenças.

Os itens elencados respaldam, entre outros, a perceção de que o universo das instituições educativas é profundamente diversificado (Sanfelice, 2006). Na realidade, mesmo considerando apenas as escolas da rede pública do ensino normal primário em Portugal que, por consequência, se enquadram no mesmo nível e modalidade de ensino, vulgo, ensino médio, as escolas do magistério primário, enquanto instituições educacionais de formação (Magalhães, 2004), conservam um significativo grau de diferenciação entre si.

Diversidades que configuram marca de cultura própria já que se as instituições educativas transmitem a cultura escolar, não deixam de ser produtoras de culturas, "cuja especificidade lhes confere uma identidade histórica” (Magalhães, 2004, p. 125).

Instituições educativas que constituem uma realidade dentro de outra realidade, concitadas, à escala nacional e internacional, a uma 
norma política e uma estrutura educativa, é na relação dialética entre a liberdade e autonomia dos atores e a norma e a estrutura que emerge o espaço de atualização identitária (Magalhães, 2004), na justa medida em que a "fidelidade dos actores aos seus objectivos, interesses e estratégias" se opõe ao "normativismo burocrático" gerando o que Licínio Lima define como "infidelidades normativas" (Lima, 1998, p. 176), por outro, porque a mutação dos contextos políticos, económicos e sociais levam a alterações mais ou menos circunstanciais que abrem possibilidades a peculiaridades por via das vicissitudes históricas de cada estabelecimento de ensino. Neste sentido encara-se a Escola do Magistério Primário de Coimbra como “[...] um contexto específico de acção, certamente marcado por dimensões políticas, jurídicas, formais e estruturais de diverso tipo, mas também pelas capacidades de agenciamento e intervenção dos actores individuais e colectivos" (Lima, 2008, p. 85-86).

Nesta perspetiva a nossa aproximação à Escola do Magistério Primário de Coimbra, entre 1942 e 1974, procura compaginar um olhar sobre as relações que estabelece, como instituição educativa, com o contexto geográfico e sociocultural envolvente, com estoutra abordagem à sua realidade interna enquanto "instituição, organização e comunidade, marcada por uma racionalidade pedagógica, por uma cultura e por uma autossuficiência de recursos" (Magalhães, 2004, p. 123). Em linha com o exposto, a nossa análise incide sobre os espaços e a estrutura arquitetónica dos edifícios, as áreas de organização - a pedagógica e didática e a de direção e gestão -, a estrutura sociocultural e a sua identidade cultural e educacional (Magalhães, 1999; Magalhães, 2004). Para a interpretação do seu itinerário histórico e do seu modelo pedagógico mobilizamos todos os vestígios da instituição, por via do arquivo, da memória e da museologia (Magalhães, 2004).

A Escola do Magistério Primário de Coimbra, em 1930, constituiu uma novel iniciativa de política educativa da Ditadura Nacional, saída do processo político gerado a partir de 28 de maio de 1926. Decisão que se compaginou com a extinção da Escola Normal Primária criada na Primeira República. Em Coimbra, a receção das transformações políticas experimentadas pela formação social portuguesa, ao longo do século XX, e a consequente alteração das orientações de política educativa para o ensino normal primário, traduziram sistematicamente, para além das modificações no plano institucional, substituição total (ou quase) do corpo docente (Mota; Ferreira, 2012).

O curso do magistério primário confinado 'aos elementos considerados essenciais' passava a ter a duração de dois anos, em vez dos quatro, e o plano estudos, em vez de trinta e seis, passava a ter dez disciplinas. O quadro de professores efetivos foi drasticamente reduzido (Portugal, 1930).

O clima da Escola, ao longo do primeiro lustro da década de trinta, transformou-se. O controlo moral e ideológico estendeu-se do currículo

Educação \& Realidade, Porto Alegre, v. 41, n. especial, p. 1397-1418, dez. 2016. 1399 
para a vivência quotidiana e as perseguições ideológicas e políticas do corpo docente abrangeram também os alunos-mestres recalcitrantes à conformação moral e ideológica (Portugal, 1932).

Em 1934, antigos alunos e alunos-mestres nacionalistas, movem uma campanha contra a Escola do Magistério Primário da cidade. Sob a epígrafe Onde está a Escola?, denunciam o seu ensino e a competência profissional de alguns dos seus professores. O objetivo era levar o Ministério da Instrução Pública a abrir um inquérito à Escola.

Do inquérito resultou a condenação da orientação errónea seguida na Escola, ao promover princípios ligados à Educação Nova, como a coeducação ou a escola única, consideradas doutrinas falsas que se situavam num plano antinacional e na constatação da ausência de um corte entre as tradições e práticas de formação de professores da Escola Normal Primária para a Escola do Magistério Primário de Coimbra. Em 1936 as matrículas no $1^{\circ}$ ano das escolas do magistério primário foram suspensas.

Quando a Escola do Magistério Primário de Coimbra reabriu as matrículas no $1^{\circ}$ ano, em 1942, era outra instituição que não aquela que foi objeto de inquérito e cujas matrículas tinham sido suspensas seis anos antes. Agora, programas, docentes e diretor concorriam para o cumprimento dos objetivos ideológicos e políticos do Estado Novo. A memória do ensino normal em Coimbra, da transição do século XIX para o XX, fora simplesmente apagada. Mas a realidade das mudanças não é tão linear. Há pedagogias que mudam e espaços que permanecem e espaços que se alteram e pedagogias que permanecem.

O edifício da Escola Superior de Educação, instituição do Politécnico de Coimbra, faz este mês de outubro, cinquenta e seis anos que foi oficialmente inaugurado. Foi construído de raiz e albergou, entre 1958 e 1989, a Escola do Magistério Primário daquela cidade. Esta era uma instituição de ensino médio, aqueloutra é uma instituição de ensino superior. Na verdade, a nossa constatação ilustra e confirma como os edifícios-escola têm média ou longa duração e as ações de reciclagem, nomeadamente para adequação aos sentidos das políticas educativas, não interferem com o essencial dos programas arquitetónicos originais (Escolano, 2001).

A Escola do Magistério Primário de Coimbra herdou para o seu funcionamento o edifício arrendado pela anterior Escola Normal republicana e que tinha a porta de entrada voltada à porta especiosa da Sé Velha, bem no coração urbano da cidade de Coimbra. Em 1944, a Escola do Magistério Primário de Coimbra desloca-se da Sé Velha para a Quinta da Rainha, junto à Cruz de Celas. Aqui permaneceria até 1958. Esta transferência é destacada no âmbito da rubrica Recordando..., assinada por Majoal, referindo que "[...] no nosso tempo foi transferida a Escola para as novas instalações da Quinta da Rainha. Aí respirava-se ar mais puro, divisávamos mais vastos horizontes" (1949). Como bem

1400 Educação \& Realidade, Porto Alegre, v. 41, n. especial, p. 1397-1418, dez. 2016. 
sublinhou Viñao Frago, uma escola como lugar, carece da atribuição de um espaço, estável e fixo, determinado para o ensino. Espaço com natureza própria, pensado, desenhado, construído e utilizado única e exclusivamente para esse fim (2001, p. 69). A construção de um edifício de raiz foi anunciada através da abertura de concurso, em Dezembro de 1956, tendo sido lecionadas as primeiras aulas no novo edifício da Escola do Magistério Primário, ao Calhabé, ainda que a título precário, em Outubro de 1958. O edifício só veio a ser inaugurado a 16 de Outubro de 1960 (Nogueira, 1960a). A localização não deixou de merecer elogios, endereçados ao governo e à capacidade realizadora do Estado Novo, considerando que a "[...] nossa bela Escola, integrada no moderno sector estudantil de que fazem parte o Liceu Feminino e a Escola Comercial e Industrial Brotero, é sem dúvida um dos grandes benefícios concedidos pelo Estado Novo nestes últimos anos, à nossa velha cidade dos doutores" (Nogueira, 1960a, p. 1). Os edifícios escolares, neste caso particular da Escola do Magistério e escola de aplicação, eram facilmente identificáveis pela sua localização, pelo volume, traço geométrico e símbolos, constituindo um significativo elemento pedagógico e cultural, tendo-se transformado num polo de atração urbana e, simultaneamente, de orientação do processo de urbanização.

O diretor da Escola, em entrevista, destacava que o espaço para educar era parte integrante da educação e do homem que se pretendiam implementar e criar. Acreditava-se, por isso, que se iriam atingir índices de formação de melhor qualidade em face da localização, da capacidade e dos equipamentos dos gabinetes, de cujo funcionamento dependia o aperfeiçoamento psicopedagógico e didático (Nogueira, 1960a). Um texto anónimo ensaiava uma descrição considerando que pela "[...] magnífica situação, conveniente amplitude, e acabamentos esmerados, o edifício da Escola do Magistério Primário de Coimbra [tinha] de considerar-se entre os melhores do género" (Novos..., 1960).

No novo enquadramento socio-histórico, estas escolas deveriam proporcionar a aquisição de cultura e prática pedagógicas, a realização de um estágio e preparar para a aprovação num exame de Estado, condições consideradas base para a habilitação para o exercício do magistério primário (Portugal, 1942).

O período de 1942 a 1974 pode ser subdividido, 1942-1960 e 19611974, correspondendo à vigência de diferentes planos de estudo datados, respetivamente, de 1942 (Portugal) e de 1960 (Portugal), contudo, os programas em vigor foram os aprovados em 1943 (Portugal, 1943), a despeito das transformações ocorridas na formação social portuguesa, da crescente escolarização e do reconhecimento, ao nível político, da necessidade da reforma das escolas do magistério primário.

Educação \& Realidade, Porto Alegre, v. 41, n. especial, p. 1397-1418, dez. 2016. 1401 
Quadro 1 - Plano de Estudos das Escolas do Magistério Primário

\begin{tabular}{|c|c|c|c|c|c|c|c|c|c|}
\hline & \multicolumn{3}{|c|}{1942} & \multirow[b]{2}{*}{ Total } & \multicolumn{4}{|c|}{1960} & \multirow[b]{2}{*}{ Total } \\
\hline Disciplinas & $1^{\circ} \mathrm{S}$ & $2^{\circ} \mathrm{S}$ & $3^{\circ} \mathrm{S}$ & & $1^{\circ} \mathrm{S}$ & $2^{\circ} \mathrm{S}$ & $3^{\circ} \mathrm{S}$ & $4^{\circ} \mathrm{S}$ & \\
\hline Pedagogia e didáctica geral [e História da Educação] & 5 & - & - & 5 & 4 & 4 & 1 & 1 & 10 \\
\hline Psicologia aplicada à educação & 3 & 6 & - & 9 & 4 & 3 & 3 & 2 & 12 \\
\hline Didáctica especial do [Grupo A] & - & 6 & 6 & 12 & 3 & 2 & 2 & 2 & 9 \\
\hline Didáctica especial do Grupo B & - & - & - & & 3 & 2 & 2 & 2 & 9 \\
\hline Higiene escolar & 3 & - & - & 3 & 2 & 2 & 2 & 1 & 7 \\
\hline Educação fisica & 2 & 2 & 2 & 6 & 2 & 2 & 2 & - & 6 \\
\hline Desenho e trabalhos manuais educativos & 2 & 3 & 2 & 7 & - & 2 & 2 & 2 & 6 \\
\hline Eđucação Feminina & 2 & 2 & 2 & 6 & & 2 & 1 & - & 3 \\
\hline Música e canto coral [Educação Musical] & 2 & 2 & 2 & 6 & 2 & 1 & - & - & 3 \\
\hline Legislação e administração escolares & - & - & 3 & 3 & 2 & 2 & - & - & 4 \\
\hline Organização politica e administrativa da Nação & 2 & - & - & 2 & 2 & 2 & 2 & - & 6 \\
\hline Educação moral e civica [Educação Moral] & 2 & - & - & 2 & 2 & 2 & 2 & - & 6 \\
\hline Prática pedagógica & 5 & 8 & 8 & 21 & 2 & 4 & 8 & - & 14 \\
\hline Total & 28 & 29 & 25 & & 28 & 30 & 27 & 10 & \\
\hline
\end{tabular}

Fonte: Portugal (1942; 1960).

Os planos de estudo, para além da redução do curso para três semestres que, numa ténue tentativa de correção, se passa a dois anos em 1960, conservam disciplinas de cultura pedagógica mas devidamente expurgadas do considerado excessivamente complexo e supérfluo para a função de professor do ensino primário, evitando-se conhecimentos que, no entender dos homens do regime, conduziriam ao pedantismo e nada acrescentariam ao eficiente desempenho docente. Destaque para a manutenção de disciplinas de expressões e de um terceiro grupo de disciplinas de cariz ideológico como era o caso de Educação moral e cívica, Organização política e administrativa da Nação e Educação feminina. Os programas desenvolvem-se na perspetiva de uma formação fundada em princípios morais e nacionais catolicistas.

As alterações introduzidas pelo diploma de 1960 revelaram-se muito tímidas e pouco eficientes. A manutenção dos programas tornou as modificações das disciplinas numa situação meramente nominal (Quadro 1; plano de estudos de 1960, a negrito). De resto, na Escola do Magistério Primário de Coimbra, alguns professores eram autores dos seus manuais ou sebentas, um suporte que se manteve inalterável, praticamente prosseguiu-se no que até então se fizera. Registe-se o aumento da carga letiva das disciplinas de cultura pedagógica que resulta não só do acrescentar de um semestre no curso, bem como da redução das horas atribuídas a algumas das de expressões.

Destaque para as alterações introduzidas ao nível do estágio. Em 1942, o estágio realizava-se de 1 de março a 31 de julho, fora da órbita estreita da própria escola do magistério, em escolas primárias oficiais, tendo como orientadores professores do ensino primário de reconhecida competência. A distribuição dos estágios era da competência dos diretores. Pelo diploma de 1960 o estágio passa a realizar-se nas escolas de aplicação anexas às do magistério primário, anteriormente reservadas à prática pedagógica, sendo nomeados para orientadores de estágio os professores dessas escolas. Constitui-se o conselho das escolas de 
aplicação, presidido pelo diretor e composto pelos professores daquelas escolas e pelos professores de Didática especial. Competia a estes professores coordenar o trabalho desenvolvido pelas duas instituições.

A Escola do Magistério Primário de Coimbra aparentou sempre possuir uma liderança bicéfala, assegurada pela cumplicidade social e política de dois homens, Francisco de Sousa Loureiro (1909-1979) e José Maria Gaspar (1910-1987). O primeiro, diretor, o segundo, professor de Didática Especial. A legislação, só por si, já os colocava em destaque no âmbito das Escolas do Magistério Primário, o diretor, a quem competia lecionar Pedagogia e Didática Geral, o professor de Didática Especial pela importância para a prática educativa e, especialmente após 1960, o estágio. Em Coimbra, a importância do professor de Didática tinha uma dimensão muito particular e a Escola foi sempre fruto da ação conjunta dessas duas figuras tutelares:

No tempo daquela, da anterior escola do magistério, digamos que as decisões eram tomadas em conjunto entre o diretor Loureiro e o professor Gaspar. Eles dialogavam muito e o Gaspar tinha um certo poder de convicção, pois era um homem muito respeitável em termos de ideologia e também implicava um pouco com o Loureiro que nunca se manifestou muito ideologicamente, de maneira que penso que neste tempo, no meu tempo [de aluno-mestre] a coisa era muito partilhada (Grácio, 2006, p. 305-306).

Ideias partilhadas pelos demais entrevistados e que transparece da documentação compulsada. Com percursos diferentes, mas dotados de uma sólida formação, que se entrecruzaram na EMPC. Conservando papéis e perfis diversos no espaço público, seja no campo cultural ou no político, a sua história confunde-se, a partir de certo momento da sua vida e até 1968, com a da Escola do Magistério Primário de Coimbra.

Os únicos professores da EMPC, e dos poucos no quadro dos professores das escolas do magistério primário, que publicaram as suas lições. Sousa Loureiro salienta que a publicação surge face às 'inúmeras e compreensíveis dificuldades' dos alunos e porque a experiência lhe demonstrou que a sua maioria 'não é capaz de preparar as suas lições após a explicação do Mestre, quer pela inexistência dum livro que contenha o programa [...], quer pela novidade e dificuldade de alguns assuntos, quer ainda pelo pouco hábito que os alunos trazem de realizar trabalho pessoal'. As suas lições são dedicadas à Pedagogia, 'ciência e a arte de Educação', e à didática, 'a ciência e a arte da aprendizagem' (Loureiro, 1950). No âmbito de Didática especial, José Maria Gaspar revisou a sebenta elaborada pelos alunos, ao longo das suas aulas, cortando 'apenas o que poderia parecer supérfluo ou dispersivo e nem as maiores lacunas' preencheu. Gaspar orientou o estudo da didática como 'maneira de conduzir e receber o ensino' (Gaspar, 1959).

O estágio, dimensão essencial da formação profissional docente, fica marcado, precisamente pela separação entre a formação em cultura

Educação \& Realidade, Porto Alegre, v. 41, n. especial, p. 1397-1418, dez. 2016. 1403 
pedagógica e o tempo de estágio, como nos disse Ilídio Falcão, “eram os professores orientadores e nós dávamos as aulas e fazíamos a reflexão com eles" (Falcão, 2006, p. 94). Simultaneamente escutamos nas entrevistas a impreparação dos professores orientadores selecionados, apontando-se tanto o desconhecimento, como a antiguidade e a rotina. Por rotina entenda-se, na perspetiva de Gonçalo Torgal, elaborar um plano de aula para um conteúdo há 20 anos e hoje continuar a usar o mesmo plano (2006). A par destes argumentos, existiam daqueles que acreditavam no método tradicional e possuíam fortes convicções. A propósito do seu estágio realizado na escola primária dos Olivais, afirmou-nos:

\section{Tenho um respeito enorme pela sua memória [...] o profes- sor Júlio Fragata era o mais antimodernidades, claro, nós tínhamos de dar as aulas e dávamos as aulas mas eu estou mesmo a ver o homem, de cada vez que a gente dava uma aula, o homem com certeza na aula a seguir, quando a gen- te não estava lá [...] ia fazer o contrário do que a gente tinha proposto aos miúdos [crianças] [...] (Torgal, 2006, p. 469).}

A razão de existência de uma escola são os seus alunos, como soi dizer-se no senso comum, sem crianças não há escola. Os vestígios delimitam o nosso questionamento em três faces desse poliedro que constitui o ser aluno-mestre. Que representações sobressaem? Desde logo, a questão estatística, quantos foram, qual a relação numérica entre alunos-mestres e alunas-mestras e qual o seu peso no plano nacional? Mais compreensiva estoutra, quem eram, no sentido social, socioeconómico e cultural, os alunos-mestres? Quais as suas origens? Finalmente, qual o grau de sucesso profissional?

A questão estatística emerge no projeto editorial da Escola, uma vez, pelo punho de O. (1950) que, tomando como fontes as matrículas e reportando-se ao período de 1942 a 1949, sublinha o grau de feminização do ensino primário que, de resto, em vão o Estado Novo procurou contrariar. Na realidade o número de alunos a admitir em cada escola do magistério dependia de despacho anual do Ministro de Educação Nacional (MEN) e estabelecia-se que dois terços das vagas destinar-se-iam a alunas-mestras (Portugal, 1942).

A tomada de decisão do MEN não seria meramente arbitrária e admitimos que conjugava o orçamento de Estado, as necessidades do mercado de trabalho, recordemos que a partir da década de 50 o sistema educativo português viveu em permanente expansão, com as capacidades dos estabelecimentos de ensino. Situação que parece verificar-se em Coimbra já que, com os dados que temos disponíveis, a Escola diplomou, no período 1958-1974, mais vinte alunos-mestres ano, do que no período anterior de 1945-1957, numa média anual de 120.

No cômputo global, entre 1942 e 1974, os diplomados da Escola do Magistério Primário de Coimbra representaram 7\% (2513) do total nacional (31996). De todas as conclusões, apenas 16\% (392) eram professo-

1404 Educação \& Realidade, Porto Alegre, v. 41, n. especial, p. 1397-1418, dez. 2016. 
res, tendo o magistério primário em Coimbra formado 2121 professoras (84\%), número bem superior aos dois terços definidos pela lei.

A representação mais comum, na tradição do ensino normal primário em Portugal, é evocada apontando as origens humildes dos alunos-mestres, bem como as dificuldades com que se debatiam para obterem o diploma (Duma Colega, 1955). A par com o testemunho coetâneo publicado, a análise que nos proporcionam alguns dos nossos entrevistados vão no mesmo sentido.

É absolutamente consensual a perceção das dificuldades económicas que impossibilitam sonhar com a universidade. Como nos destaca Ilídio Falcão, aluno-mestre no período de 1942-1960, professor depois e, finalmente, de 1977 a 1989, diretor da Escola, são as "pessoas mais simples, mais carenciadas, com mais dificuldades económicas” (Falcão, 2006, p. 116), aquelas que procuram o curso do magistério. Se Gonçalo Reis Torgal (2006) os situa, na escala social, na classe média baixa, o professor de Psicologia, José Queirós (2006), e o aluno-mestre Martins Grácio, associam a frequência do curso e as dificuldades económicas à origem rural, tanto mais que implicava despesas acrescidas, a deslocação e manutenção em Coimbra, durante dois anos, para os já de si magros orçamentos familiares (Grácio, 2006). Neste mesmo quadro socioeconómico, Reis Torgal convoca uma razão de natureza cultural, avançando que alguns outros optavam pela escola do magistério por tradição familiar ou contacto com a cultura escrita. Para este aluno-mestre, um grupo de colegas escolheram ser professores porque tinham tios, primos, padrinhos que eram professores ou, em alternativa, padres. Afinal, estávamos perante um curso rápido e (quase) garantia de colocação imediata. Ainda assim, nem só esta era a razão, nem tão pouco existia um só tipo de alunos.

Um outro conjunto de alunos-mestres, filhos de boas famílias e de gente licenciada, para utilizar a expressão do professor José Queirós, optava pelo curso do magistério, normalmente por sucessivos fracassos escolares no $3^{\circ}$ ciclo do ensino liceal, em abono da verdade, continuamos a seguir a narrativa de José Queirós, na maior parte das vezes por cabulice e não por dificuldades cognitivas ou outras (Queirós, 2006, p. 175). Ora, nem todos conviviam com dificuldades económicas no dia-a-dia. Martins Grácio explicou-nos que as desigualdades eram detetáveis para quem estivesse atento, distinguindo-se os alunos-mestres pelas roupas que vestiam mas também pela disponibilidade, ou não, que tinham para, nas viagens, consumir e realizar despesas num café ou noutro estabelecimento comercial.

Condições económicas à parte existiam, até porque não devemos perder de vista a variável invocada por Reis Torgal, alunos-mestres com capacidades e tão capazes como quaisquer outros. Como nos testemunhou José Queirós, ele lecionou a 'alunos que não eram nada inferiores' e adianta que "[...] não eram nada deficientes até depois na prática mui-

Educação \& Realidade, Porto Alegre, v. 41, n. especial, p. 1397-1418, dez. 2016. 1405 
tos deles se formaram e não foi assim raro, não é, [foi] uma percentagem mesmo muito grande, e [alguns chegaram] até à cátedra das faculdades" (Queirós, 2006, p. 175). Gonçalo Torgal concretiza mesmo, a título de exemplo, com nomes de professores da Universidade de Coimbra, sendo que alguns nem chegaram sequer a exercer no ensino primário (Torgal, 2006).

Finalmente, não pela cátedra mas evocando outros percursos, no Rumo destacava-se o orgulho pelo desempenho profissional dos antigos alunos-mestres da Escola do Magistério Primário de Coimbra, especialmente nas estruturas do Ministério da Educação Nacional, em Portugal e nas colónias, sinónimo da qualidade de formação da Escola (Duarte, 1952), algo que era assumido como resultado do esforço coletivo mas também individual (Elevação, 1965). Na retórica, algo gongórica e ao sabor da época, de diferentes artigos compulsados, a formação transformava-os, de acordo com os objetivos pretendidos, em jovens que partilham um sonho, um ideal (Oliveira, 1954) e a mesma luz como guia, aguardando a hora de combate para servirem sob a bandeira de Deus, a Pátria, a Família e o Trabalho (Pessoa, 1953). Num contexto que exige respeito mútuo e cumprimento do dever sem constrangimento (Lopes, 1955), são apresentados - os alunos-mestres - como dotados de confiança e vontade para vencer (Oliveira, 1957) e, como escrevia na época o nosso entrevistado Joaquim Grácio, cumprir a missão que abraçaram no momento em que ingressaram na Escola do Magistério Primário de Coimbra (Grácio, 1954).

O nosso acesso ao clima, ao ambiente, da Escola do Magistério Primário de Coimbra é muito marcado pelas representações construídas pelos alunos e alunas-mestras no espaço público que constituía o Rumo. Não surpreende que num ensaio de abertura solene de um ano letivo, em 1965, se enalteça que, naquela Escola, a camaradagem, a amizade e a compreensão andam, e andaram, sempre de mãos dadas (A Escola..., 1965).

O ambiente da escola foi sendo sistematicamente caracterizado com recurso a expressões como festas de família (Vila, 1956) ou esta nossa casa, sintetizada pelo aluno-mestre António Lourenço, na sua locução aos alunos e alunas do $1^{\circ}$ ano, quando sublinhava que 'na nossa Escola, encontrareis um acolhedor ambiente familiar' (Pedro; Lourenço, 1956, p. 2). O mesmo familismo encontramos, cerca de uma década mais tarde, quando o diretor, Francisco de Sousa Loureiro, invetiva contra os detratores da Escola, destacando o ambiente familiar que nela se vivia (A Escola..., 1965).

As narrativas para caracterizar as relações entre alunos e alunas mobilizam palavras e ideias, signo e significado, como alegria, amizade, camaradagem e respeito. Ideias-chave que perpassam e ecoam ao longo do período estudado. De resto, as sucessivas reuniões anuais dos diferentes cursos que ocorrem ainda nos dias de hoje, contribuem para 
a consolidação dessa imagem. Afinal, como se testemunha na plaquete (folheto com caricaturas dos alunos da turma e versos) do curso de 1959-1961 “[...]E unidos seremos amanhã”.

Na verdade, a preocupação do respeito articulada com a relação de ajuda mútua (Envergonhada, 1956), prendia-se com o caráter inusitado da convivência entre sexos, num tempo em que a coeducação fora proscrita pelo regime político e os seus partidários e banida, pelo menos do ponto de vista formal e até onde a estreiteza do orçamento o permitiu, do sistema de ensino. A relação entre os sexos, já em plena década de sessenta, foi sempre objeto de vigilância apertada ou de preocupação orientadora, fosse por orientação superior da direção da escola ou por mera iniciativa pessoal ou convicção religiosa.

Na relação e diálogo que estabelece com os alunos-mestres, o diretor não se coíbe de adotar uma postura, e um tom, paternalista, nomeadamente, a propósito de uma relação de namoro. Quando analisámos a questão da relação entre alunos-mestres e professores, Joaquim Grácio, um protegido de Francisco Sousa Loureiro - chegava a orientar as aulas do próprio diretor na sua ausência (Grácio, 2006) -, narra-nos a atitude de Sousa Loureiro como exemplo das cordiais relações entre alunos-mestres e professores:

[...] havia uma relação de amizade e solidariedade muito grande entre os próprios professores e os alunos, e mesmo entre os alunos também, inclusivamente, eu namorava a minha mulher, lembro-me que o Dr. Loureiro me chamou, duas vezes ou três:

Ouve lá, andas para aí com outras colegas e a Maria Eugénia a chorar pelos cantos?, estava a ver o tipo de relação que havia.

Vê lá pá, vê lá coitada, então ela anda para aí a chorar,

Ó Sr. Dr. então, eu estou num curso, tenho as colegas, acabámos uma aula, há perguntas, há problemas e tal, falo com elas normalmente[...]

Pois, mas vê lá, coitada, a Maria Eugénia é boa rapariga, [a Maria Eugénia é minha mulher] é boa rapariga, vê lá e tal[...], está a ver, isto chegava assim a este ponto de relação, não é, o que parece bastante positivo (Grácio, 2016, p. 301-302).

É, por vezes, ténue a linha que separa a amizade e confiança da preocupação com o controlo e a disciplina. A imagem que se guarda é que os alunos-mestres e as alunas-mestras reconheciam nos professores uma atitude bondosa, carinhosa e paciente e que os docentes mobilizaram todo o seu saber, fé e carinho para os esclarecerem e tornarem aptos (Pedro, 1956), num contexto de amizade sincera (Monteiro, 1956), partilhando alegrias e tristezas (Vila, 1956). Cada um no seu lugar parece sintetizar a relação entre professores e professoras com o corpo discente. O corpo docente testemunha que agiu para além do ambiente

Educação \& Realidade, Porto Alegre, v. 41, n. especial, p. 1397-1418, dez. 2016. 1407 
escolar na tentativa de compreender os reais problemas de alunos e alunas, bem como salientam que os discentes procuraram cumprir com o dever, no sentido de atingirem objetivos comuns, pois comungavam de ideais (Mendes, 1965) que os uniam (Pedro; Lourenço, 1956). Um exemplo marcante desta preocupação de compreender os contextos dos rapazes e raparigas, para além dos muros da escola, pelo menos no que isso influenciava os resultados escolares dos alunos-mestres, e, portanto, importava ter esses elementos em consideração é-nos dado por D. Eurico Dias Nogueira (2006, p. 249):

E da parte dos professores havia um interesse muito grande pelos alunos. Eu ficava admirado, eu conto-lhe um caso [...] vamos para uma reunião de professores e, enfim, passamos em revista os alunos todos, tinham feito exame de saída ou coisa parecida, e com surpresa, uma rapariga, que era boa aluna, caiu. [...] todos os professores, 'mas esta rapariga era boa aluna', e até é mais, tinha uma bolsa de estudo e, perdia a bolsa, [...] 'mas como é que é possível esta rapariga, aqui há-de haver um problema grave', e encarregamos uma das senhoras professoras, não é, de secretamente [...]: 'veja lá o que é que se passa com essa rapariga' [...] passados uns dias comunica-nos: 'olhem, a moça é muito pobre, veio, é filha de uma senhora viúva, mas enfim com aspiração de tirar um curso, veio da aldeia para aqui com a mãe, alugaram um quartito, umas águas furtadas para as duas, [...] e a mãe cozinhava para a filha e enfim, a mãe teve um derrame cerebral, ficou inutilizada e pobre rapariga passou a ter que olhar pela mãe [...]'. Ouvimos aquilo e dissemos: 'bem, não vamos prejudicá-la relativamente à bolsa de estudos', e resolvemos ali dar-lhe a nota equivalente, forçar, em vez do onze dar-lhe o catorze à mesma, embora depois fosse avisada 'no exame final tens as notas que mereceres, não é' [...].

As relações, percebidas na sua dimensão intra e entre corpos, docente e discente, quer na sua dimensão intersubjetiva, evoluem quotidianamente e, simultaneamente, são instituintes de organizações existentes no âmbito escolar mas, de igual modo, são por elas moldadas. Neste domínio, o quotidiano da Escola do Magistério Primário de Coimbra (EMPC) parece encerrar algumas particularidades, já que, provavelmente devido a alguns dos seus protagonistas, este foi profundamente marcado por vivências religiosas de confissão católica.

As narrativas sobre a marca de uma vivência religiosa católica são consensuais ainda que com posicionamentos e opções de retórica. Confrontado com a questão sobre a existência, ou não, de uma vivência religiosa promovida pela EMPC, Gonçalo Reis Torgal foi cristalino, "isso não tenha dúvidas nenhumas, promovida pela Escola”, esclarecendo, ainda, que ninguém seria obrigado a rezar o terço todos os dias ou a benzer-se à entrada de cada sala. Contudo, continuamos escutando Reis Torgal, incutia-se a prática do status quo religioso, o ir à missa, fa- 
zer o mês de Maria, entre outros aspetos, referindo que 'a própria escola fazia o mês de Maria, não é, para quem queria e ninguém era obrigado'. E como que adotando uma postura de equidistância e consciente da sua narrativa sobre aquela realidade de há mais de meio século, desocultando uma dimensão que não deixava de caracterizar e marcar as relações e o clima da escola, destaca que 'haveria talvez alguns que fossem por uma questão de dizer: ó pá, se eu não vou começam a dizer que eu não vou; e iriam, pois iriam'. Mas por via desta vivência religiosa a própria escola envolvia-se na comunidade e participava numa procissão da cidade, com intervenção direta dos alunos e do seu diretor, como nos narra Gonçalo Torgal, "a Escola participava na grande procissão de Corpo de Deus que era uma procissão importantíssima em Coimbra” e depois de destacar que antes da entrevista foi verificar os elementos, procurando conferir fidedignidade ao seu trabalho de rememoração, afirma que "o diretor era uma das pessoas chamada para levar o pálio, numa das varas" (Torgal, 2006, p. 459).

A própria escola possuía, no seu seio, organizações católicas que enquadravam, dentro e fora de portas, a vida e ação das alunas e dos alunos-mestres. Como nos explica Ilídio Falcão, existiam três organizações que, em seu entender, tinham um estatuto diferente no modo como se relacionavam com a instituição EMPC. Eram elas, as Conferências de S. Vicente de Paulo que "funcionavam dentro da Escola", atuando "de dentro para fora”, a LEC, "uma Liga Escolar Católica [que] era uma organização, portanto, que funcionava paralela, digamos assim, à Escola” e a Liga Intensificadora de Ação Missionária (LIAM) que "era de fora para dentro" (Falcão, 2006, p. 126). Pelo seu trabalho paralelo, para utilizar a expressão deste nosso entrevistado, a LEC não deixou vestígios ou o seu impacto apenas se sentia pela ação individual dos seus membros.

As Conferências de S. Vicente de Paulo, dizemos conferências pois existiam a feminina e a masculina, reuniam periodicamente e os seus membros dedicavam-se à recolha de bens e a visitar e a distribuir bens pelos pobres e enfermos (Falcão, 2006). A existência da conferência vicentina masculina, denominada S. João Maria de La Salle, remonta ao primeiro lustro da década de trinta do século passado, uma iniciativa patrocinada por um professor da EMPC e figura grada na cidade de Coimbra, o padre Luiz Lopes de Melo e cujo primeiro secretário foi o nosso já conhecido professor José Maria Gaspar, ao tempo, ainda aluno-mestre. As reuniões decorriam e continuaram a realizar-se no Centro Académico de Democracia Cristã, CADC, fundado, entre outros, por António de Oliveira Salazar. De acordo com o livro de atas, as reuniões conheceram uma interrupção entre 1934 e 1944, não percamos de vista a existência da EMPC nesse período, e em 1949 o secretário será o aluno-mestre Ilídio de Jesus Coelho Falcão. Na verdade, o livro de atas é interrompido pouco depois, ainda que a Conferência tivesse prosseguido a sua ação, pelo menos, até 1974 .

Educação \& Realidade, Porto Alegre, v. 41, n. especial, p. 1397-1418, dez. 2016. 1409 
É, contudo, sobre a conferência feminina que possuímos indicadores sobre a sua ação. Na realidade, como assinalámos anteriormente, é sempre complexa e ténue a linha entre apoio desinteressado e a vontade de uma ação disciplinadora e conformadora ou a delimitação entre informação útil e a devassa e desrespeito da vida privada. Neste entendimento, discutir e analisar a vida familiar de uma aluna-mestra, em sede de reunião de Conferência de São Vicente Paulo feminina da EMPC, e apreciar as suas condições materiais de existência e daí inferir conclusões sobre o seu comportamento social, dentro e fora da Escola, pode trazer consequências. Não sabemos se se tratou de caso isolado ou se eram procedimentos comuns mobilizando a caridade cristã para atuar sobre comportamentos sociais condenáveis no seio da EMPC, o que temos conhecimento é que num caso resultou na denúncia por parte da família e a aluna acabou por perder o ano letivo. É o que rememoriza connosco a professora Maria de Lurdes Matos, aluna-mestra no período de 1961 a 1974, na primeira pessoa:

[...] vinha-me embora e estou sentada ao lado de uma colega Maria de Lurdes Castelhano, nunca me esquece desta colega que vinha de Mira, uma menina muito querida, muito boa rapariguinha e, olho para o caderno que ela tem ao lado e vejo descrito a minha pessoa, sem o meu nome, ou seja, com tópicos e tinha lá reunião de São Vicente Paulo, vinha lá o meu perfil, e que eu identifiquei perfeitamente [...] (Matos, 2006, p. 598-599).

Pela narrativa de Maria de Lurdes Matos, na reunião da Conferência tinham analisado todo o seu comportamento, dentro e fora da escola, família, namorado, etc. O problema foi desvalorizado pelo padre responsável da Conferência tendo considerado a aluna-mestra sui generis, 'uma pessoa especial, enfim', 'uma atleta' e que, em razão disso, tinha 'um comportamento mais livre'. A questão acabou por envolver o pai da aluna e esta acabou reprovando nesse ano. Como nos explica Maria de Lurdes, a convivência com aquelas colegas, naquele momento, tornara-se insustentável: "foi um ano que foi ao ar, porque os conflitos eram tantos, percebe, eu sentia-me tão mal, tão mal, eu não conseguia estar ali dentro" (Matos, 2006, p. 600). Um incidente que deixa perceber uma maior complexidade e densidade no processo de socialização no âmbito da EMPC.

De natureza diferente, como destacou Ilídio Falcão, era a LIAM, para a qual existiam peditórios e se chegava a interromper as aulas para o efeito (Queirós, 2006). Com origens em 1937, iniciou o seu movimento de penetração nas Escolas do Magistério Primário em 1959 (Neiva, s. d.). A sua presença na escola de Coimbra manifestou-se sobretudo por via das festas $(1961,1962)$ e os encontros em que se empenharam, pelo menos, um professor, José Maria Gaspar, e um conjunto de alunos e alunas-mestras.

1410 Educação \& Realidade, Porto Alegre, v. 41, n. especial, p. 1397-1418, dez. 2016. 
Às festas que, aparentemente, o principal objetivo era a imposição das insígnias aos novos liamistas, era conferido carácter institucional, envolvendo a Escola que se fazia representar pelo seu diretor e os corpos docente e discente. Sempre presente a cerimónia religiosa da missa que na festa de 1961 foi mesmo celebrada dentro da Escola, tendo para o efeito sido fabricado um altar. Em geral, além da cerimónia religiosa, compunham a festa, algumas variedades, discursos ou conferências, encerrando com a passagem de filmes com carácter recreativo e cultural e sobre "assuntos relativos à Acção Missionária no Ultramar Português” (Martins, 1962, p. 5). A LIAM tinha um núcleo devidamente organizado na Escola do Magistério Primário de Coimbra que realizava reuniões semanais (Gaspar, 1964, p. 7) e participava regularmente nos encontros da Liga.

O quotidiano da EMPC, com o decorrer dos anos letivos, ficou marcado por dois momentos festivos, primeiro, a festa de receção aos alunos e às alunas do $1^{\circ}$ Ano, preparada pelos do $2^{\circ}$ Ano, por vezes, também designada pela festa da castanha. Um outro momento festivo, preparado pelos do $1^{\circ}$ ano, consistia na despedida dos/das colegas do $2^{\circ}$ Ano. Por alturas da $2^{\mathrm{a}}$ metade da década de 60 , ensaiou-se uma abertura solene do ano letivo.

Em 1955, Maria Eugénia Pedro escreveu uma frase publicada no Rumo que confere escala à festa da castanha: “[...] as tradições e costumes nacionais representam sagrados altares e devem ser para nós fogos sempre acesos de amor a Portugal" (Pedro, 1955, p. 1). Apresenta-nos um raro momento de consonância entre a ideologia e a política educativa de um regime, o Estado Novo, as representações (escritas) dos atores e as práticas educativas desenvolvidas na Escola do Magistério Primário de Coimbra.

Em Portugal é vasto o panorama das festas ligadas ao quotidiano do mundo rural (Oliveira, 1984) (Oliveira, 1987) que foi sujeito a um processo de cristianização dos cultos e celebrações pré-cristãos fundado nas figuras do cristianismo (cristo, a virgem, os apóstolos, os mártires e os santos). É o caso do dia 11 de novembro, dia de São Martinho, o apóstolo das Gálias, que o ditado popular populariza: no dia de São Martinho, mata o teu porco e prova o teu vinho. Uma segunda nota a ter em consideração é a ação desenvolvida no quadro do Estado Novo, após um século de liberalismo, no sentido da apropriação seletiva e na "depuração transformativa” (Silva, 1994, p. 209) da cultura popular, de que são exemplo, as romarias (Sanchis, 1992) ou o arraial na comunidade de São Torcato (Silva, 1994).

A festa da castanha tem lugar na Escola, pela Escola, para a Escola - estão presentes os alunos e as alunas, os professores e as professoras e o diretor (A Escola..., 1965). O ginásio que não o era (Sousa, 2006), primeiro, e o salão de festas, depois, constituíam-se em espaço para a realização de um sarau, cuja duração variou ao longo dos anos e onde,

Educação \& Realidade, Porto Alegre, v. 41, n. especial, p. 1397-1418, dez. 2016. 1411 
antes das atividades de palco, se assistia à intervenção de um aluno-mestre do $2^{\circ}$ ano que dava as boas-vindas aos colegas do $1^{\circ}$ ano, ao que estes, no momento do encerramento, retribuíam com um agradecimento em nome dos novos.

O sarau agregava um conjunto de atividades de palco que foi variando ao longo dos cerca de trinta anos, envolvia habitualmente, a atuação do Orfeão da Escola, peças de teatro e revista, jograis, declamação de poesia, danças diversas - do barroco à persa -, a atuação de conjuntos musicais, um naipe de iniciativas que concitava os esforços dos alunos-mestres.

Findo o sarau teria lugar o magusto, com a particularidade simbólica de as fogueiras serem acesas por antigos alunos. Do convívio no Magusto resultava a confraternização, um conhecimento mais íntimo e as enfarruscadelas. O espaço de realização da festa só muito pontualmente foi fora das quatro paredes da Escola (1948, 1949 e 1956). Será em meados da década de cinquenta que entra em cena um baile, apresentado como familiar e com a função social de consolidar os laços fraternais (Lopes, 1955).

A festa de 1964 coincide com a abertura do ano escolar, num programa recheado de eventos inusitados e pouco comuns, onde se incluiu uma homenagem ao antigo Ministro da Educação Nacional Leite Pinto, sendo descerrada uma lápide no átrio da Escola e um retrato na biblioteca. José Queiroz, professor da disciplina de Psicologia, proferiu uma conferência intitulada A função actual da escola. Pela primeira vez, num acontecimento que parece ilustrar alguma abertura à comunidade e uma aproximação às leituras da educação pelo viés do capital humano e do ocedeísmo, o Conselho Escolar atribuiu o prémio D. Dinis, a conceder ao melhor aluno de cada ano, um prémio instituído pela Sociedade Central de Cervejas (Homenagem..., 1965).

A cerimónia das cerimónias era a Consagração ao Sagrado Coração de Maria. Cerimónia de forte carga simbólica, uma manifestação de fé à Virgem Maria, da parte dos alunos-mestres e das alunas-mestras no momento de conclusão do seu curso. A cerimónia, habitualmente precedida de um retiro e de uma missa, encerrava com a leitura da fórmula de consagração (Nogueira, 1960b). Conheceu diferentes locais na cidade, da Capela das Carmelitas à Sé Velha, da Igreja de S. José ao ginásio da Escola do Magistério Primário de Coimbra. Por duas vezes ocorreu em Fátima, em 1952 e 1967.

Na década em que Fátima se constituiu, definitivamente, no altar do mundo, os alunos-mestres que compunham a direção do Rumo (A Direcção..., 1953), decidem equacionar a consagração - cerimónia 'já tradicional' em todas as escolas do magistério, coletiva e de 'expressiva espiritualidade' - de todos os finalistas do Magistério Primário, em Fátima (Aos Finalistas..., 1952).

1412 Educação \& Realidade, Porto Alegre, v. 41, n. especial, p. 1397-1418, dez. 2016. 
A iniciativa enquadrou a renovação dos votos pelos professores e pelas professoras (Uma Ideia..., 1952; Aos Finalistas..., 1952), proposta que o Ministério da Educação Nacional acolheu e concedeu justificação de falta aos docentes que participassem no evento. A iniciativa envolveu, ainda, a organização de uma peregrinação, para a qual se constituiu um 'numeroso grupo' (Aos Finalistas..., 1952, p. 1), partindo de Coimbra até ao santuário de Fátima, e coincidindo a chegada com a cerimónia de consagração.

Na análise que centrámos na EMPC buscámos, afinal, delinear uma identidade cultural e educacional naquela instituição educativa, não descurando a procura de mudanças e permanências, bem como de desarticulações (e conformidades) entre a norma e as práticas sociais.

A especificidade da EMPC sobressai no seu percurso histórico, seja pela receção das transformações políticas que atravessaram a sociedade portuguesa mas igualmente, como se percebeu, pelo transporte da legitimidade política para a educação, do fim da República para o Estado Novo, ter tido o seu centro nevrálgico em Coimbra e na sua escola do magistério. Sublinhe-se que é a partir do inquérito realizado à EMPC que as matrículas nas escolas do magistério primário são suspensas. Certos atores essenciais neste processo foram protagonistas na nova vida da EMPC, a partir de 1942.

O périplo da EMPC por espaços e edifícios diferentes, permite ver o quanto a educação é refém das condições materiais de existência já que eles condicionam o modo como se perspetiva a educação e condicionam fortemente as experiências educativas. Frequentar e ser aluno-mestre na EMPC, quando esta se localizava na quinta da Rainha, é radicalmente diferente de o ser quando se situou no Calhabé. Pelos edifícios e espaço ocupados pela instituição, que oferecem outras possibilidades de experiências educativas, bem como a própria experiência de vida de estudante, no entorno, é outra. É a mesma instituição como uma outra.

Estamos diante de uma escola mas ela não é uma qualquer, apesar de organizar-se de acordo com o padrão que a insere num sistema escolar. Ela inscreve-se na trama dos tempos, do político, do cultural, na dinâmica socioeconómica e na visão e da capacidade do Estado. Mas as suas peculiaridades identitárias arreigam-se ainda no modo como se gere e vive o que lhe foi destinado. Se a norma é tantas vezes percebida como limitadora da ação, a sua ausência não torna os atores pró-ativos. Na realidade, a transformação do plano de estudos, devido à ausência de publicação dos programas, aparentemente, não justificou o ajustamento da parte do corpo docente. A crer que as sebentas constituem uma aproximação relevante ao desenvolvimento dos conteúdos, nem o aumento significativo das cargas letivas conduziu à sua alteração. É disso exemplo, a disciplina de Didática que se desdobrou em duas e passou de uma carga letiva de doze horas para dezoito horas. Na mesma linha mas considerando a limitação ao nosso questionamento, não podemos

Educação \& Realidade, Porto Alegre, v. 41, n. especial, p. 1397-1418, dez. 2016. 1413 
deixar de relevar que mesmo com a alteração profunda que o estágio sofreu, de 1942 para 1960, tal não emergiu nas narrativas de rememorização que recolhemos. Mas viu-se que, como tantas vezes sucede, as perspetivas pedagógicas dos estagiários são tantas vezes divergentes das dos orientadores que os supervisionam.

Ao nível do clima da escola vimos que os discursos conservadores dominantes funcionaram e procurámos imagens dissonantes que permitissem complexificar as relações entre alunos-mestres e entre estes e os seus professores. As imagens projetadas no Rumo, as narrativas dos nossos entrevistados bem como outra documentação compulsada, vão no sentido da afirmação de um familismo, de uma camaradagem e amizade, de uma felicidade quase ucrónica. Na realidade até nas melhores famílias existem conflitos. A entrevista sobre as reuniões da Conferência vicentina, do sexo feminino, funcionou como um sinal disruptor desta visão, indício da complexidade das relações no contexto escolar e do impacto que estas podem ter na aprendizagem mas também no processo de desenvolvimento pessoal e social de cada um.

No quadro das festas é ineludível a conformidade entre um governo que articula os valores da ruralidade e da tradição católica de modo a naturalizar uma compreensão de mundo fortemente conservadora e uma ordem social e política estática. Ainda assim, mesmo neste quadro foi possível traçar linhas evolutivas e até uma certa abertura ao ocedeísmo.

Sobressai igualmente a incapacidade de, através de uma política educativa alterar o processo evolutivo das sociedades. Isso é especialmente evidente na tendência para a feminização do corpo docente do ensino primário. Em face das transformações da sociedade portuguesa, a entrada das mulheres, de certos setores sociais, no mercado de trabalho era uma inevitabilidade e os valores, à época, conduziam-nas para as áreas da saúde e da educação. Naturalmente, ao nível da escola, a norma nunca seria cumprida.

Recebido em 30 de julho de 2016 Aprovado em 02 de outubro de 2016

\section{Referências}

A DIRECÇÃO do Rumo presta homenagem àqueles que até Fevereiro tão nobremente souberam dirigir o nosso jornal - Gonçalo José R. Torgal, Manuel Bernardo, Cipriano dos Santos e José Maria Nogueira. Rumo, Órgão dos Alunos da Escola do Magistério Primário de Coimbra, Coimbra, p. 2-31, ago. 1953.

A ESCOLA esteve em Festa. Rumo, Órgão dos Alunos da Escola do Magistério Primário de Coimbra, Coimbra, p. 6, 1 fev. 1965.

AOS FINALISTAS do país. Rumo, Órgão dos alunos da Escola do Magistério Primário de Coimbra, Coimbra, p. 1, 15 jan. 1952.

DUARTE, Urbano. Em dois anos muito andam. Rumo, Quinzenário dos Alunos da Escola do Magistério Primário de Coimbra, Coimbra, p. 3, 15 jun. 1952.

1414 Educação \& Realidade, Porto Alegre, v. 41, n. especial, p. 1397-1418, dez. 2016. 
DUMA COLEGA, M. L. O meu caso. Rumo, Quinzenário dos Alunos da Escola do Magistério Primário de Coimbra, Coimbra, p. 2, 15 fev. 1955.

ELEVAÇÃO humana. Rumo, Órgão dos Alunos da Escola do Magistério Primário de Coimbra, Coimbra, p. 1, 1 out. 1965.

ENVERGONHADA, Caloira. Carta para longe. Rumo, Quinzenário dos Alunos da Escola do Magistério Primário de Coimbra, Coimbra, p. 2-3, 15 dez. 1956.

ESCOLANO, Agustín. Arquitetura como programa. Espaço-Escola e currículo. In: VIÑAO FRAGO, António; ESCOLANO, Agustin (Org.). Curriculo, Espaço e Subjetividade: a arquitetura como programa. Rio de Janeiro: DP\&A, 2001. P. 20-57.

FALCÃO, Ilídio de Jesus Coelho. Entrevista a um aluno-mestre no período de 1942-1960, professor nos períodos seguintes e diretor na normalização e anos 80. In: MOTA, Luís. Ideologia, Memória e História. A Escola do Magistério Primário de Coimbra (1942-1989). 2006. Tese (Doutorado em Letras) - Universidade de Coimbra, Coimbra. P. 57-141. (Entrevista concedida a Luís Mota. Anexo I - Entrevistas, Tomo II).

GASPAR, José Maria. Apontamentos de Didáctica Especial. Coimbra: Livraria Almedina, 1959.

GASPAR, Quim. Pela Pátria. Rumo, Órgão dos Alunos da Escola do Magistério Primário de Coimbra, Coimbra, p. 7, 1 dez. 1964.

GRÁCIO, Joaquim Martins. Entrevista a um aluno-mestre no período de 19421960. In: MOTA, Luís. Ideologia, Memória e História. A Escola do Magistério Primário de Coimbra (1942-1989). 2006. Tese (Doutorado em Letras) - Universidade de Coimbra, Coimbra. P. 289-317. (Entrevista concedida a Luís Mota. Anexo I - Entrevistas, Tomo II).

GRÁCIO, Joaquim Martins. Saudação aos novos colegas. Rumo, Quinzenário dos Alunos da Escola do Magistério Primário de Coimbra, Coimbra, p. 1, 1 nov. 1954.

HOMENAGEM ao Prof. Eng. Leite Pinto, Ministro da Educação na altura em que se construiu o actual edifício da nossa Escola. Rumo, Órgão dos Alunos da Escola do Magistério Primário de Coimbra, Coimbra, p. 1-5, 1 jan. 1965.

LIMA, Licínio. A "escola” como categoria na pesquisa em educação. Educação Unisinos, São Leopoldo, v. 12, n. 2, p. 82-88, maio/ago. 2008.

LIMA, Licínio. A Escola como Organização e a Participação Escolar: um estudo da escola secundária em Portugal (1974-1988). Braga: Centro de Estudos em Educação e Psicologia/Instituto de Educação e Psicologia/Universidade do Minho, 1998.

LOPES, Álvaro. Festa de recepção aos antigos colegas. Rumo, Quinzenário dos Alunos da Escola do Magistério Primário de Coimbra, Coimbra, p. 1, 31 dez. 1955.

LOUREIRO, Francisco de Sousa. Lições de Pedagogia e Didáctica Geral. Coimbra: Depositária Livraria Gonçalves, 1950.

MAGALHÃES, Justino. Contributo para a História das instituições educativas entre a memória e o arquivo. In: FERNANDES, Rogério; MAGALHÃES, Justino (Org.). Para a História do Ensino Liceal em Portugal. Braga: Universidade do Minho, 1999. P. 63-77.

MAGALHÃES, Justino. Tecendo Nexos: história das instituições educativas. Bragança Paulista: Editora Universitária São Francisco, 2004.

Educação \& Realidade, Porto Alegre, v. 41, n. especial, p. 1397-1418, dez. 2016.1415 
MAJOAL. Recordando... Rumo, Jornal dos Alunos da Escola do Magistério Primário de Coimbra, Coimbra, p. 1-2, 22 abr. 1949.

MARTINS, José Alberto Ferraz. A festa da LIAM. Rumo, Órgão dos Alunos da Escola do Magistério Primário de Coimbra, Coimbra, p. 5, 1 fev. 1962.

MATOS, Maria de Lurdes. Entrevista a uma aluna-mestra no período de 19611974 e professora e orientadora de estágio durante as Experiências Pedagógicas. In: MOTA, Luís. Ideologia, Memória e História. A Escola do Magistério Primário de Coimbra (1942-1989). 2006. Tese (Doutorado em Letras) - Universidade de Coimbra, Coimbra. P. 593-651. (Entrevista concedida a Luís Mota. Anexo I - Entrevistas, Tomo I).

MENDES, José Maria Amado. Apreciação ao Ano Escolar. Rumo, Órgão dos Alunos da Escola do Magistério Primário de Coimbra, Coimbra, p. 1, 1 jul. 1965.

MONTEIRO, Jorge. Aos Novos. Rumo, Quinzenário dos Alunos da Escola do Magistério Primário de Coimbra, Coimbra, p. 2, 1 out. 1956.

MOTA, Luís; FERREIRA, António Gomes. Instituições de ensino normal primário público em Coimbra (1901-1989). In: PINTASSILGO, Joaquim (Org.). Escolas de Formação de Professores em Portugal. Lisboa: Edições Colibri, 2012. P. 149204.

NEIVA, Adélio Torres. Animação Missionária Espiritana em Portugal. Lisboa: Missionários do Espírito Santo, s. d. Disponível em: <http://www.espiritanos. org>. Acesso em: 15 ago. 2005.

NOGUEIRA, Taborda. Escola em festa - A inauguração do novo edifício é bem uma festa escolar portuguesa. Rumo, Quinzenário dos Alunos da Escola do Magistério Primário de Coimbra, Coimbra, p. 1-4, 15 out. 1960a.

NOGUEIRA, Taborda. Festa da Consagração do Curso de 1958-60. Rumo, Quinzenário dos Alunos da Escola do Magistério Primário de Coimbra, Coimbra, p. 1-4, 15 mar. 1960b.

NOGUEIRA, Eurico Dias. Entrevista a um professor no período de 1942-1960. In: MOTA, Luís. Ideologia, Memória e História. A Escola do Magistério Primário de Coimbra (1942-1989). 2006. Tese (Doutorado em Letras) - Universidade de Coimbra, Coimbra. P. 237-289. (Entrevista concedida a Luís Mota. Anexo I - Entrevistas, Tomo II).

NOVOS Edifícios da Escola do Magistério Primário de Coimbra. Rumo, Quinzenário dos Alunos da Escola do Magistério Primário de Coimbra, Coimbra, p. 1,15 out. 1960 .

O., C. O Movimento da E. do M. Primário de Coimbra. Rumo, Jornal dos Alunos da Escola do Magistério Primário de Coimbra, Coimbra, p. 2, 21 jan. 1950.

OLIVEIRA, Ernesto Veiga. As Festas, um Passeio pelo Calendário. Lisboa: Fundação Calouste Gulbenkian, 1987.

OLIVEIRA, Ernesto Veiga. Festividades Cíclicas em Portugal. Lisboa: Dom Quixote, 1984.

OLIVEIRA, Maria Isabel. Olhos no futuro. Rumo, Quinzenário dos Alunos da Escola do Magistério Primário de Coimbra, Coimbra, p. 1, 3, 2 jan. 1957.

OLIVEIRA, Rosinda. Uma Carta. Rumo, Quinzenário dos Alunos da Escola do Magistério Primário de Coimbra, Coimbra, p. 2, 15 mai. 1954.

PEDRO, Lucas Simões; LOURENÇO, António. A nossa festa. Rumo, Quinzenário dos Alunos da Escola do Magistério Primário de Coimbra, Coimbra, p. 2-4, 1 dez. 1956.

1416 Educação \& Realidade, Porto Alegre, v. 41, n. especial, p. 1397-1418, dez. 2016. 
PEDRO, Maria Eugénia. Aos que vão partir. Rumo, Quinzenário dos Alunos da Escola do Magistério Primário de Coimbra, Coimbra, p. 2, 15 mar. 1956. PEDRO, Maria Eugénia. Frase. Rumo, Quinzenário dos Alunos da Escola do Magistério Primário de Coimbra, Coimbra, p. 1, 1 dez. 1955.

PESSOA, Madalena Faria. O nosso sonho. Rumo, Quinzenário dos Alunos da Escola do Magistério Primário de Coimbra, Coimbra, 1 de julho de 1953, p. 1.

PORTUGAL. Decreto n. ${ }^{\circ}$ 18646, de 19 de julho de 1930. Institui as escolas do magistério primário, destinadas à preparação do professorado primário, elementar e infantil, em substituição das escolas normais primárias, que ficam extintas. Diário do Governo, Lisboa, n. 166, série I, 19 jul. 1930. P. 1443-1450.

PORTUGAL. Decreto n. ${ }^{\circ}$ 21695, de 29 de setembro de 1932. Reorganiza o ensino de preparação para o magistério primário. Diário do Governo, Lisboa, n. 229, série I, 19 set. 1932. P. 1963-1970.

PORTUGAL. Decreto-lei n. ${ }^{\circ} 32243$, de 5 de setembro de 1942. Regula o funcionamento das escolas do magistério primário. Diário do Governo, n. 208, série I, 5 set. 1942. P. 1139-1143.

PORTUGAL. Decreto-lei n. ${ }^{\circ} 32629$, de 16 de janeiro de 1943. Programas das escolas do magistério primário. Diário do Governo, n. 12, série I, 16 set. 1943. P. 31-41.

PORTUGAL. Decreto-lei n.o 43369, de 2 de dezembro de 1960. Altera o plano de estudos das escolas do magistério primário e insere outras disposições relativas ao funcionamento das referidas escolas. Diário do Governo, n. 279, série I, 16 dez. 1960. P. 2674-2676.

QUEIRÓS, José Fernando Alves. Entrevista a um professor entre os dois períodos do Estado Novo, 1942-1960. In: MOTA, Luís. Ideologia, Memória e História. A Escola do Magistério Primário de Coimbra (1942-1989). 2006. Tese (Doutorado em Letras) - Universidade de Coimbra, Coimbra. P. 141-185. (Entrevista concedida a Luís Mota. Anexo I - Entrevistas, Tomo II).

SANCHIS, Pierre. Arraial: Festa de um Povo. As romarias portuguesas. Lisboa: Dom Quixote, 1992.

SANFELICE, José Luís. História, Instituições Escolares e Gestores Educacionais. Revista HISTEDBR On-line, Campinas, UNICAMP, número especial, p. 20-27, ago. 2006.

SILVA, Augusto Santos. Tempos Cruzados. Um Estudo Interpretativo da Cultura Popular. Porto: Edições Afrontamento, 1994.

SOUSA, Maria do Céu Antunes Almeida da Cruz. Entrevista a uma professora dos cinco períodos definidos, desde o Estado Novo, 1942-1960 e 1961-1974, às Experiências Pedagógicas, passando pela normalização até aos anos 80. Desempenhou ainda outras funções na Escola Superior de Educação. In: MOTA, Luís. Ideologia, Memória e História. A Escola do Magistério Primário de Coimbra (1942-1989). 2006. Tese (Doutorado em Letras) - Universidade de Coimbra, Coimbra. P. 522-547. (Entrevista concedida a Luís Mota. Anexo I - Entrevistas, Tomo I).

TORGAL, Gonçalo Reis. Entrevista a um aluno-mestre no período de 1942-1960. In: MOTA, Luís. Ideologia, Memória e História. A Escola do Magistério Primário de Coimbra (1942-1989). 2006. Tese (Doutorado em Letras) - Universidade de Coimbra, Coimbra. P. 433-502. (Entrevista concedida a Luís Mota. Anexo I - Entrevistas, Tomo II).

Educação \& Realidade, Porto Alegre, v. 41, n. especial, p. 1397-1418, dez. 2016. 1417 
UMA IDEIA do rumo - aos finalistas do país, Rumo, Órgão dos Alunos da Escola do Magistério Primário de Coimbra, Coimbra, p. 1-2, 15 fev. 1952.

VILA, Maria Lucília. O Magusto e o seu significado. Rumo, Quinzenário dos Alunos da Escola do Magistério Primário de Coimbra, Coimbra, p. 3, 1 mar. 1956.

VIÑAO FRAGO, António. Do espaço escolar e da escola como lugar: propostas e questões. In: VIÑAO FRAGO, António; ESCOLANO, Agustin; VEIGA-NETO, Alfredo (Org.). Curriculo, Espaço e Subjetividade. A Arquitetura Como Programa. Rio de Janeiro: DP\&A, 2001. P. 59-139.

Luís Mota é doutor em História da Cultura pela Universidade de Coimbra. Professor adjunto do Politécnico de Coimbra, na Escola Superior de Educação (PC, ESE). Investigador integrado e vice-coordenador científico do Grupo de Políticas e Organizações Educativas e Dinâmicas Educacionais, do Centro de Estudos Interdisciplinares do Século XX, da Universidade de Coimbra (GRUPOEDE, CEIS20, UC).

E-mail: mudamseostempos@gmail.com

António Gomes Ferreira é doutor em Ciências da Educação pela Universidade de Coimbra. Professor associado e diretor da Faculdade de Psicologia e de Ciências da Educação, da Universidade de Coimbra (FPCEUC). Investigador integrado e coordenador científico do Grupo de Políticas e Organizações Educativas e Dinâmicas Educacionais, do Centro de Estudos Interdisciplinares do Século XX, da Universidade de Coimbra (GRUPOEDE, CEIS20, UC).

E-mail: antonio@fpce.uc.pt 